\title{
Local Pride Movement as A Local Sneaker Branding Strategy
}

\author{
${ }^{*}$ Suseno, Bayu Aji \& ${ }^{2}$ Hidayat, Anwar \\ ${ }^{*}$ Institut Seni Budaya Indonesia Tanah Papua \\ ${ }^{2}$ Politeknik Akademi Teknologi Kulit Yogyakarta \\ Note: * Indicates corresponding author
}

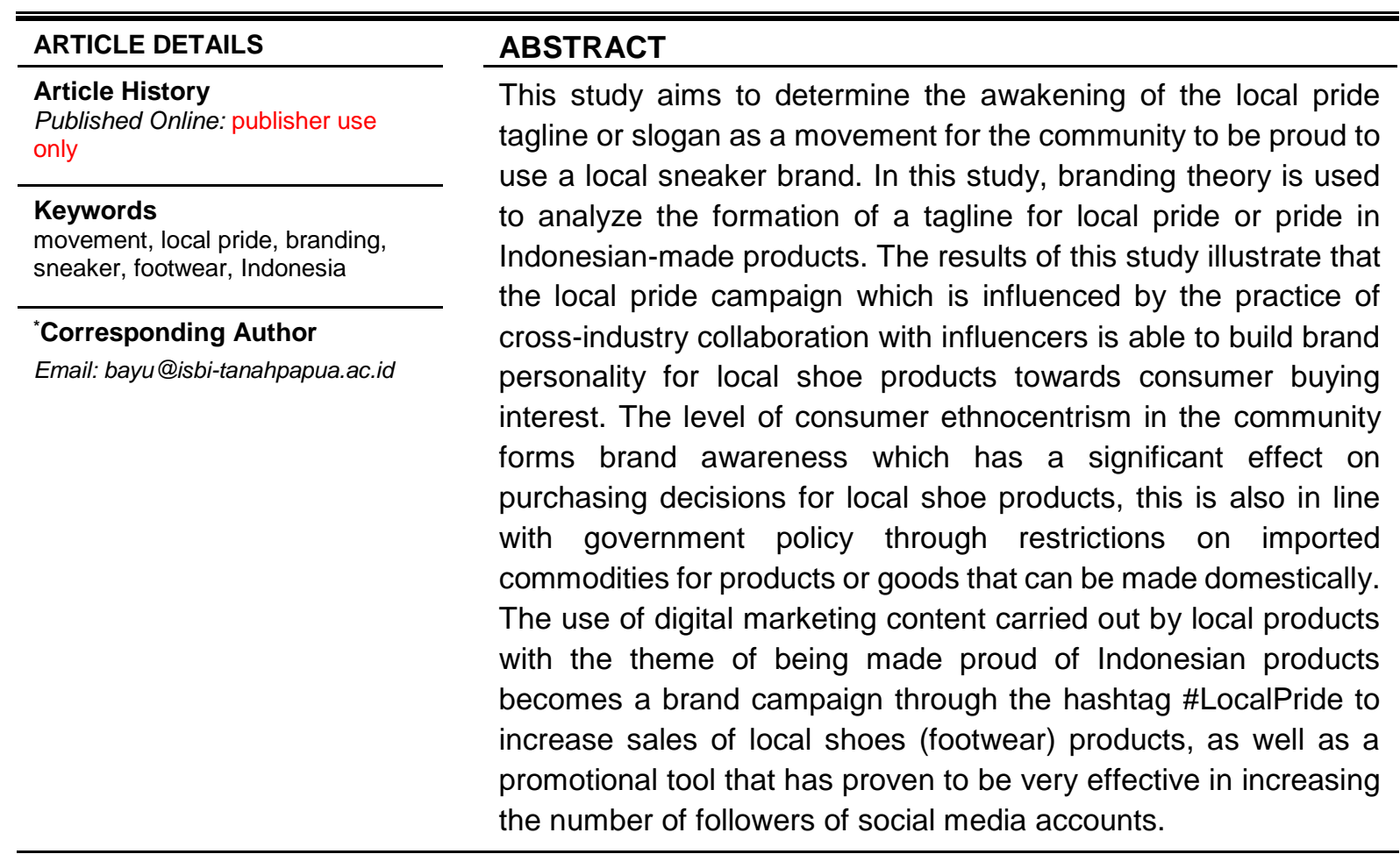

\section{Introduction}

Shoes are a product that not only serves to protect human feet, but is also one of the most important clothing supports that can affect a person's appearance or style. Each individual looks attractive but also chooses a particular brand to increase his social status in society. Types or models of shoes (footwear) sneaker are becoming a trend or fashion style, especially among teenagers or the millennial generation (young) because their shape is always up to date and following the times. In Indonesia, many local sneaker brands are found with varying prices with quality and design. In the last four years, the local sneaker industry in Indonesia has been increasing with a variety of new brands popping up. Before 2010, other local sneaker brands started to grow, such as Nah Project, Ventela, Brodo, Pijak Bumi, Heiden Heritage, Thanksinsomnia, Imperior Footwear, FYC (Forever Young Crew), Word Division, ARL, Immune, Amble, Mathilda, Patrobas, Exodos 57, Poison Street, Superrior, Homskin x Rupaka, Faculty of Economics and Business, Brawijaya University
Johnson, Rafheoo, KEM, ODM, Livehaf, Volca, Vermillion, Footstep, Portegoods, Sage, Waleza, Standrich, Mine, Guteninc, Syrup Supply, Elfamous, Habibtat, Directions, Fuse , Gasch, SB x HC, Rage Guerrilla Vestement, Sans, Fearclub, Brotherhood and so on. The existence of local sneakers is increasingly in demand by the community, especially young people (millennial generation), this has an impact on the emergence of the local pride movement or proud to wear made in Indonesia. The local pride tagline was pioneered by local footwear producers in Indonesia to increase public awareness that these local sneakers are no less in quality than imported sneakers.

Local has a meaning in the class of nouns, so that local can express the name of a person, place, or all objects and all objects and adjectives or adjectives. Locale can change a noun or pronoun, usually by explaining it or making it more specific. By definition, local pride is an effort to support or use products made in the country. A product can be said to be locally made, if the product material comes from within 
the country and the labor comes from within the country, then the product uses a local brand and finally the local ownership of the company. The stretching of local sneakers has indeed felt massive, especially in the last two years. The popularity of local sneakers is used by producers (sellers) to digitally market these footwear products to the public through social media such as Instagram and websites. The increasing number of internet users in Indonesia in the ecommerce sector currently has many positive impacts on the development of the local sneaker industry. Product marketing strategies through social media can reach a wider market share, and are able to increase sales of a product or item to potential consumers. One example is by scrolling through the feed on the Instagram social media platform using the hashtag \#LocalPride and \#LocalPridelndonesia, consumers can easily find various local sneaker brands made in Indonesia. If viewed from a historical perspective, exposing the history of the origin of the new term \#LocalPride has actually been popularized by the government through the Love Indonesian Products campaign in 2009.

The local pride tagline that has been echoed so far has a very significant effect on the rapid purchasing power of the people for domesticmade shoes (footwear). The local pride campaign that rides the spirit of pride in local products makes Indonesian-made sneakers even more successful in their own country. In an effort to increase the prestige of local sneaker brands so that they are not unable to compete with imported products. Local shoe brand manufacturers continue to develop and innovate through cross-industry collaboration with influencers in producing limited edition sneakers. In order to increase sales of these footwear products, local sneaker manufacturers use a pre-order system (PO) sales strategy by using an estimated time of ordering. In addition, there are also many sneaker exhibition agendas on a national and international scale, such as the Jakarta Sneaker Cult, the Urban Sneaker Society (USS), or the Jakarta Sneaker Day (JSD). The existence of the annual sneaker event which is starting to thrive in the country has become a communication space and educational facility for local sneaker enthusiasts, including producers (sellers), collectors and sneaker communities.

In this study, the theoretical basis of branding is used to analyze the formation of the local pride tagline. Branding is a form of modern marketing strategy that is widely used by entrepreneurs to market products or services to be sold traditionally or online (Kotler, 2006: 22). Brand is a name, term, sign, or design or a combination of all that is expected to identify goods or services from a person or group of sellers (Sunyoto, 2012: 102). In building a product or service brand, a branding strategy is needed that not only aims to improve marketing but also understands the needs and wants of buyers (consumers). Brand strategy is a defines what a brand should achieve in relation to consumer attitudes and behavior (Gelder, 2005: 29). Schultz and Barnes in Strategic Brand Communication Campaigns (1999) added that brand strategy is also called brand communication which can be interpreted as brand management as a communication system that connects products or services with stakeholders in supporting marketing activities of a brand to consumers. The branding strategy seeks to place the product in a competitive position with other products. Strategy is the best way to use funds, available manpower in accordance with the demands of environmental change (Siagian, 1996: 17). Based on the background that has been stated, the problem of this research is how the local pride movement becomes a branding strategy for local sneaker products in Indonesia. The purpose of this study was to determine the revival of the tagline or slogan of local pride as a movement for the community to be proud to use a local sneaker brand.

\section{Research Methods}

In this study using a qualitative approach. Qualitative research is research that intends to understand the phenomena experienced by research subjects holistically and by means of descriptions in the form of words and language, in a special natural context and by utilizing various natural methods (Moleong, 2011: 6). In the research subject, the researchers selected research samples consisting of local sneaker brand manufacturers such as Compass and Nah Project, as well as organizing sneaker exhibition agendas in Indonesia which were held from 2017 to 2019, including the Jakarta Sneaker Cult, Urban Sneaker Society ( USS), and Jakarta Sneaker Day (JSD). The data collection techniques used in this study included observation, documentation (photos and videos) and written literature, both printed and electronic. Observations were made by researchers to obtain the required information related to the study of the object of research. In this study the researcher used non-participant observation by not being actively involved in the informant's life but only being an independent observer. Documentation studies are used to strengthen the results of observations made by researchers. Literature or literature to collect information relevant to the topic or problem 
becomes the object of research. This information can be obtained from books, scientific papers, theses, dissertations, encyclopedias, internet, and other sources.

\section{Results And Discussion}

\subsection{Cross-Industry Collaboration with Local Sneaker Brands with Influencers}

Sneaker is a type of footwear (shoes) that has a flexible bottom or outsole because it is made of rubber or a synthetic material of the TPR (Thermo Plastic Rubber) type, while the upper is made of materials such as leather, canvas, suede. and nylon. In the local sneaker industry in Indonesia, shoe brands that are produced from collaborative projects with influencers have become fashion products that are much sought after by sneakerheads. The term sneakerhead first appeared in the early 1980 s in the United States and is usually divided into two groups, namely basketball fans and hiphop music fans. Sneakerhead is a name for people who have a hobby of collecting sneaker shoes to meet fashion needs as well as to support fashion styles. Not only collecting and wearing sneaker shoes, sneakerheads also often sell and buy special or limited edition shoes to fellow sneaker fans, or modify them to get a higher selling price (Dharmawan \& Handoyo, 2017: 5) . Collaboration is a process to achieve a goal that will not be possible individually. In collaboration to build interrelated systems to solve problems and opportunities to achieve the desired results. Brand collaboration can be done by exchanging ideas and co-creation of a product through a new design.

Looking back, the long history of sneaker collaboration culture was started by Vans Old Skool with Supreme in 1996. Moving on to the next year, Reebok Pump Fury produced sneakers with the high fashion brand Chanel. In 2003 , he opened a collaborative model between a sneaker brand and a graffiti artist from New York named Josh Franklin (Stash). This collaboration paved the way for sneaker collaboration with other artists, such as KAWS, Eric Haze, Mark Ong, Futura, Keith Harring, Basquiat and so on. Air Jordan is one example of a successful shoe brand collaboration that has lasted a long time. Nike built a marketing strategy for these shoe products by choosing the basketball athlete (NBA) icon Michael Jordan as the brand ambassador, and replacing the iconic swoosh (tick) logo on Nike shoes with a silhouette of Michael Jordan doing a slamdunk (jumpman). The trend of shoe brand collaboration with influencers among artists or

Faculty of Economics and Business,

Brawijaya University musicians such as Adidas shoes which collaborated with rapper Kanye West to produce the Adidas Yezzy Boots sneaker in 2014. If observed, the collaboration of sneakers with influencers such as musicians, artists and sportsmen has actually been started by the Converse Rubber Corporation or which is known as the Converse shoe brand. Initially, Converse Inc produced footwear and seasonal work shoes based on rubber, then decided to produce hightop sports shoes used for playing basketball. In 1921, Converse took Charles Henry Taylor or who is usually called Chuck to join the sales promotion of these shoes. Chuck Taylor is a player and coach of The All-Stars basketball team sponsored by Converse. Thanks to his immense service to the company, Converse added the Chuck Taylor signature to the logo on the ankles of Converse shoes. In today's era, Converse shoes have shifted to become a symbol of counter-culture or anti-mainstream, especially for rockets and hipsters.

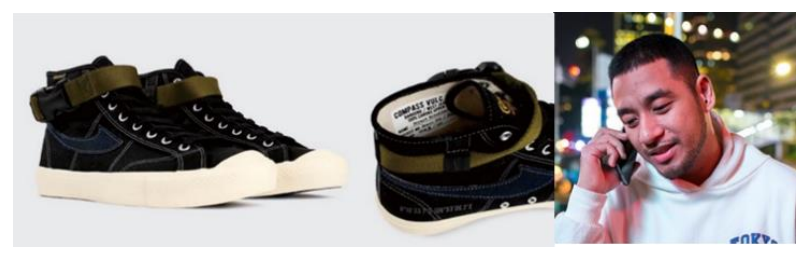

Figure 1. Compass Bravo Sneakers

Source : @sepatucompass (2019)

In collaboration with local sneaker brands in Indonesia, Compass shoes launched the Compass Bravo sneaker edition, which is the result of collaboration with influencer Brian Notohadihardjo at the Jakarta Sneakers Day 2019 event. Compass Bravo shoes use canvas as the basic material used on the upper, while the soles use techniques retread. Vulcanized or the vulcanizing process is the assembly of rubber to make it stronger using high temperature heat. In the outsole technique, the process is relatively rough and difficult to control the quality, usually only low-end shoe products can be produced. Shoes with the vulcanizing technique are more comfortable and economical to wear, and have high efficiency and low cost in production, so that the process is still applied in the production of rubber shoes and leather shoes with a large amount of production. The Compass Bravo shoe design carries a military style with black canvas on the upper, as well as the addition of an extra buckle in army green that is attached to the top of the Gazelle Hi silhouette which is the hallmark of the Compass shoe logo. On the tongue, Bryant's writing was given as a sign of the collaboration between the Compass shoe brand and the influencer Bryant 
Notohadihardjo. Compass Bravo shoes are sold online within 1.5 hours and are produced in a limited number of 100 pairs at a price of $\mathrm{Rp}$. 398,000. In 2020, Compass is bringing out sneakers to celebrate the tenth anniversary of the Mata Najwa television program. On the tongue of the sneaker with the Mata Najwa edition, there is a red square label that says Sepatu Compass untuk Mata Najwa and underneath is the logo of the television program. Only ten pairs of these special edition sneakers were produced by Compass in keeping with the anniversary year of the Mata Najwa television program. Mata Najwa television program titled talk show hosted by Najwa Shihab is a female presenter and journalist whose figure really inspires others because she is able to be critical of issues that develop in the social and political fields.

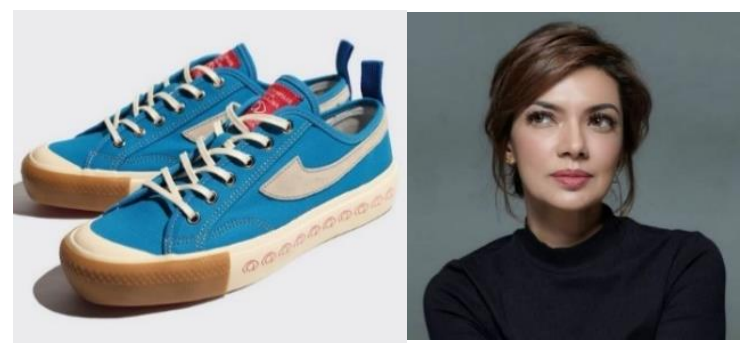

Figure 2. Compass Sneakers for Mata Najwa Source : @urbansneakersociety (2020)

The NAH Project and AX Indonesia and Makna Creative are the result of a collaboration between a local sneaker brand and men's grooming products and a creative agency. AX is a male grooming product brand owned by the multinational company Unilever, while Makna Creative is a creative lab or creative laboratory engaged in advertising with output in the form of print, video, and other visual content. Makna Creative was founded by Ernanda Putra and Keenan Pearce in 2013. In the shoe upper, the sneaker uses a mono translucent type of material made of nylon fiber which has a waterproof or splashproof feature, while the sole (shoe bottom) uses thermo plastic rubber (TPR) material which able to reduce the impact in the foot when used for walking or running. The technique of applying the transparency material (monotranslucent) for sneakers from the collaboration of NAH Project and AX Indonesia and Makna Creative is the first time used in the local sneaker industry in Indonesia. The $\mathrm{NAH}$ Project carries a retro futurism and deconstructed style by applying a more playful mixed material and a choice of two colors that seem eye catching, namely black and white. The $\mathrm{NAH}$ Project released two sneakers from the collaborative results on July 14, 2019 at a price of IDR 475,000, which were produced around 3,000 pairs. The local sneaker brand $\mathrm{NAH}$ Project was founded in 2017 in Bandung by Rizky Arief Dwi Prakoso and Karina Innadindya. The NAH Project has become a local sneaker brand that has skyrocketed in the country because it was used by the President of the Republic of Indonesia, Joko Widodo at the We the Fest 2018 music festival.

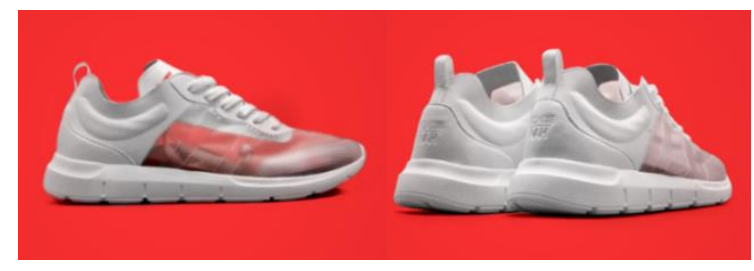

Figure 3. Sneakers NAH Project X AXE Indonesia $X$ Makna Creative

Source : @sepatucompass (2019)

On April 19, 2020, the NAH Project also released a sneaker in collaboration with Kevinsworks entitled Don't Keep It To Yourself. Kevin Lagona Tarigan or Kevinsworks is an illustrator and graphic designer who posts his work through Instagram social media. The pastel-colored NAH Project and Kevionswork sneaker designs give off a cheerful and fun impression to remind and sensitize people to mental health. In 2019, Kevinsworks previously collaborated with local sneaker brand Pijak Bumi to create a shoe made from environmentally friendly materials at the Urban Sneaker Society (USS) event. The NAH Project and Kevinswork sneaker shoes are produced in a limited number of 357 pairs at a price of IDR 599,000. Crossindustry collaboration for local sneaker brands with automotive companies initiated by the National Modificator and Aftermarket Association (NMAA). Saint Barkley launched the cullen slip on sneaker series in collaboration with the Datsun and Educate Yourself car brands in the Indonesia Modification Expo event which took place on November 17-18 2018 at Balai Kartini, Jakarta. Educate Yourself is a movement built by Dochi Sadega, a member of the pop rock band Pee Wee Gaskins. When viewed from the definition, influencers are individuals or collaborate in a group (community) with a large number of followers, but business developments in the digital era that allow companies to promote a product or service geographically are not only based on the location of the company. potential consumers known as hyperlocal influencers (Krabuanrat, 2007). In forming a content strategy, hyperlocal influencers contribute or respond to a product or service by representing a concern for a community or group of people who have the same interests and habitats. 


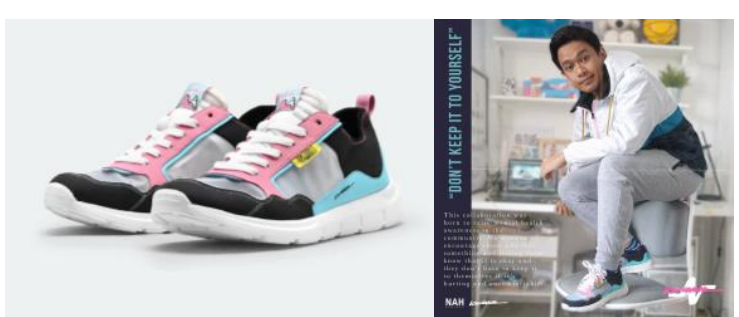

Figure 4. Sneakers NAH Project $X$ Kevinsworks

Source : @nahproject (2020)

Cross-industry collaboration with local sneaker brands using influencer marketing strategies, apart from being able to reach a broader target market but also becoming a brand personality that aims to attract consumer interest by becoming an emotional marketing strategy towards product purchasing decisions based on the influence of these influencers. Brand personality is a way that aims to increase the attractiveness of the brand from outside in the eyes of consumers (Gelder, 2005: 41). According to Crainer and Dearlove (2003), brand personality is a brand that is obtained from a character through communication about the brand and the experience of the brand as well as from the person who introduces the brand. According to language discipline, influencers are people who have a large number of followers or audience on social media and have a strong influence on their followers, such as artists, celebrities, bloggers, YouTubers, and so on. One of the factors that underlie the success of using influencer marketing to increase product sales, as well as presenting a good corporate brand image to consumers. Marketing of a product or service using an influencer is considered effective in increasing sales and creating brand awareness for potential consumers, this is due to the influence of the influencer being the first or trendsetter for his followers. Influencer marketing is a method of appointing people or figures who are considered to have influence among the community or target consumer segments who will be targeted and considered to be the promotional targets of the brand (Hariyanti \& Wirapraja, 2018: 128). Collaboration across the local sneaker industry is a method used by manufacturers in order to build a brand personality from these footwear products for consumers. Marketing activities of a product by borrowing an already established brand or attaching it to other products in order to increase sales, and become part of a marketing strategy by introducing a product brand to consumers. The collaboration strategy becomes utility by trying to boost public trust based on the similarity of the big names of the local sneaker brand manufacturers. Collaboration across sectors is very much needed to advance the micro, small and medium enterprises sector in Indonesia, including the local footwear (shoe) industry.

Joel Blake and David Ernst in Collaborate to Compete in the Global Market (1993) explain that in the future there will be an increase in collaboration strategies compared to competition strategies as an effort to welcome the occurrence of cross-border economic and business relations. Collaboration between local sneaker brands and influencers is a marketing strategy concept to create content that has quality and meaning, so that it becomes a storytelling that is produced by linking the relevance or relationship of an influencer and his followers. Local sneaker brands using influencer marketing strategies can have a significant impact and a positive relationship to brand awareness, either directly or indirectly through customer engagement as an intermediary. Thus, customer engagement is to describe the affinity between consumers and producers through an interaction, reaction, effect, or experience that is felt by the customer as a whole with the product or item. Apart from using influencers to build brands and consumer relations, local sneaker product brands also often involve KOL (Key Opinion Leader) in their marketing strategies. KOL (Key Opinion Leader) which is commonly used in digital business by making an influencer as a person who will influence the attitudes and behavior of consumers shown in these products or goods. Marketing strategy using influencers to expand the target market is similar to the VisCAP model which consists of four elements, namely visibility, credibility, attraction and power. Visibility has a dimension of how big the celebrity's popularity is. Credibility relates to product knowledge known to celebrities. Attraction focuses more on celebrity attractiveness. Power is a celebrity's ability to attract consumers to buy these products or goods (Royan, 2004: 14).

\subsection{Consumer Ethnocentrism to Local Sneaker Brand Awareness}

The Indonesian footwear industry grew steadily in line with the development of the Indonesian economy which took place in the early 1980s. Entering the early 1990s, the Indonesian footwear industry boomed with the entry of foreign investors who specialized in producing export footwear. The footwear industry has experienced improvement with the demand for domestic goods which became the foundation of the reform era in 2000. The 
government participated in cooperation with APRISINDO (Asosiasi Persepatuan Indonesia) in helping the footwear industry to develop even more. The growth of the footwear industry in Indonesia in recent years has progressed further with the increase in the number of footwear production reaching 1.41 billion in 2018 . Indonesia is in the fourth position as a footwear producer in the world after China, India and Vietnam, this is reflected in its value. footwear industry exports in 2016 which increased by $2.95 \%$ compared to the previous period with a surplus of USD 4.15 billion. In addition, there was also a very significant increase in investment in the leather and leather products and footwear industries, which reached almost four times the investment in the previous year, which was IDR7.62 trillion (Permana, 2017: 3).

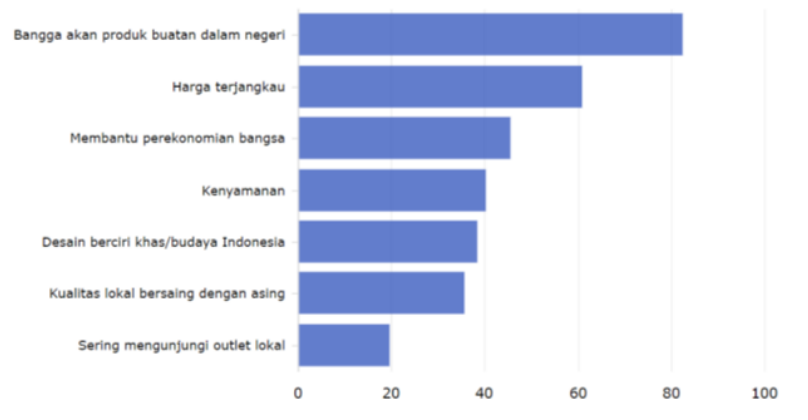

Figure 5. Reasons for Indonesian Consumers to Choose Local Products Source : Katadata Insight Center (2020)

The government develops the national footwear industry by encouraging the growth of micro, small and medium enterprises through training and fostering a certified professional workforce and increasing competence and productivity of human resources (HR) in the footwear industry based on Standar Kompetensi Kerja Nasiona Indonesia (SKKNI) In addition, the implementation of regulations and programs is carried out in a stimulant manner through a campaign of love for domestic products in every line of economic activity, such as Gerakan Bangga Buatan Indonesia (GBBI) or $100 \%$ Cinta Indonesia. The revival of the local sneaker market share that is increasing sharply is able to increase the sense of nationalism towards products or goods made in the country, this can be seen from a survey conducted by the Katadata Insight Center (2020) to find out the reasons consumers choose local products. Public trust in domestic products is quite high, reaching $93.3 \%$ compared to consumer confidence in foreign products valued at $71.5 \%$. In the survey, there were 6,697 respondents drawn from 34 provinces in Indonesia who argued that they used local products due to the

Faculty of Economics and Business, Brawijaya University fact that the price of local products is more affordable $(60.7 \%)$, helps the country's economy (45.4\%), and local quality competes with foreign products $(35.6 \%)$.

The increase in the local brand shoe industry is also driven by public trust in domestic footwear exhibition activities that carry out sneaker-themed events from 2017 to 2019. The proliferation of sneaker exhibition events is the result of collaboration from stakeholders, such as manufacturers (sellers), collectors and sneaker communities in Indonesia. Stakeholders are any groups inside or outside the organization that have an influence on the success of the company (Kasali, 1994: 63). Stakeholders are individuals, groups, communities or society as a whole who can influence or be influenced by the actions, decisions, policies, practices, or goals of the organization. Stakeholders can also be said to be public, but not all publics are stakeholders. The public is a part of society, whether small or large, minority or majority groups who have some common interests and goals in certain situations. Exhibition is a form of promotional activity that allows interaction between producers and consumers. Exhibitions are also very often carried out for promotional events which aim to attract the attention of potential customers.

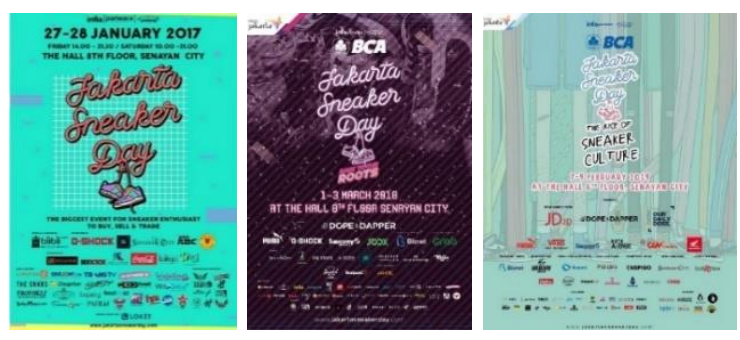

Figure 6. Jakarta Sneaker Day Exhibition

Source : www.jakartasneakerday.com (2018)

The increase in the local brand shoe industry is also driven by public trust in domestic footwear exhibition activities that carry out sneaker-themed events from 2017 to 2019 . The proliferation of sneaker exhibition events is the result of collaboration from stakeholders, such as manufacturers (sellers), collectors and sneaker communities in Indonesia. Stakeholders are any groups inside or outside the organization that have an influence on the success of the company (Kasali, 1994: 63). Stakeholders are individuals, groups, communities or society as a whole who can influence or be influenced by the actions, decisions, policies, practices, or goals of the organization. Stakeholders can also be said to be public, but not all publics are stakeholders. The public is part of society, whether small or large, exhibition groups are essentially all activities intended to convey or communicate a 
product to the public, then provide information about its features, uses and most importantly about its existence to change attitudes or encourage people to buy it. (Leorensi, 2010: 22). An exhibition activity is held by a company or industry to demonstrate the latest products and services by studying the activities of competitors and following current trends, as well as opening up opportunities to expand market share. Increased enthusiasm for local brand shoe businesses from the participation of local sneaker brand manufacturers in the largest sneaker exhibition in Indonesia, such as the Jakarta Sneaker Cult, Urban Sneaker Society (USS), or the Jakarta Sneaker Day (JSD). Jakarta Sneaker Day was held at The Hall Senayan City on January 27 - 28 2017. The Jakarta Sneaker Day event with the theme Sneaker Fashion Culture was held in collaboration with Infia Media Pratama with a number of sneakers communities in Indonesia. The next Jakarta Sneaker Day event with the theme The Rise of Sneaker Culture will be held on March 1 - 3, 2018 and February 7 - 9, 2019. In this exhibition, sneakerheads (sneaker fans) can also shop for sneakers online through an ecommerce site. JD.ID.

The Urban Sneaker Society (USS) was held for the first time on 28-30 April 2017, while the second event was held again from 29 September to 1 October 2017 at Grand Indonesia. The event was initiated by a well-known sneaker community in Jakarta, namely Local.co.id and North Sneaker Squad. The Urban Sneaker Society (USS) event was held for the third time on 9-11 November at Pacific Place Mall SCBD, Jakarta. The Urban Sneaker Society (USS) exhibition is a media of information about the development of sneaker shoes in Indonesia, such as old or latest sneaker brands and models made locally and abroad (imported). The existence of the Urban Sneaker Society (USS) exhibition not only provides education about sneaker shoes, but also presents other streetwear fashion products at relatively cheap prices with the mission of lifting local sneaker brands (Cherri, 2020: 2). The biggest sneaker exhibition ever held in Indonesia is the Jakarta Sneaker Cult. The event is the biggest pop-up sneaker market in Indonesia, organized by MRA Media through Esquire Indonesia magazine. This sneaker-studded Jakarta Sneaker Cult event was held on October 20 - 222017 at JIExpo Kemayoran, Jakarta. Jakarta Sneaker Cult showed off 20 legendary sneakers on the Wall of Fame, as well as the 20 best sneakers from the Sneaker Cult Custom Competition which were exhibited at the end of the event
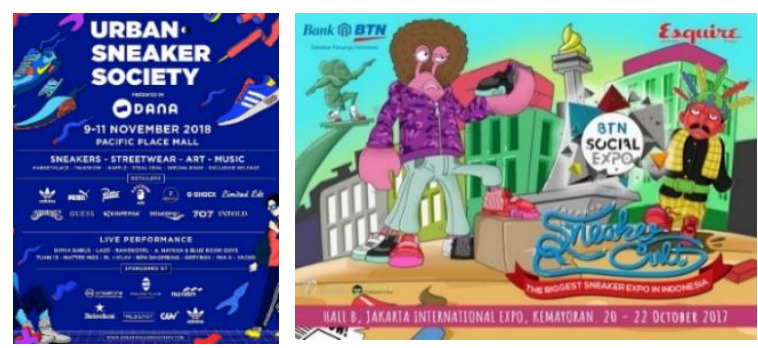

Figure 7. Urban Sneaker Society \& Jakarta Sneaker Cult

Source : www.urbansneakersociety.com \& www.harpersbazaar.co.id (2018)

The concept behind the birth of the brand is brand campaign at the 2019 Urban Sneaker Society exhibition is made differently from each previous year by equalizing local shoe products with imported shoes. Thus, the exhibition is a brand positioning for stakeholders, such as producers (sellers), collectors and sneaker communities in Indonesia, which aims to change the stigma that domestic-made shoe brands are not less competitive in design and quality than artificial shoes. overseas. In a product or goods marketing strategy, brand positioning is a way to demonstrate the advantages of a brand and its difference from other competitors (Gelder, 2003: 32). According to Susanto and Himawan Wijanarko in Building Superior Brands and Supporting Organizations (2004) explained that brand positioning is part of the brand identity and value proposition that is actively communicated to target consumers and shows its superiority to competitors' brands. Based on the goal, brand positioning is a strategy from the producer to win over and dominate the minds of customers through the products offered.

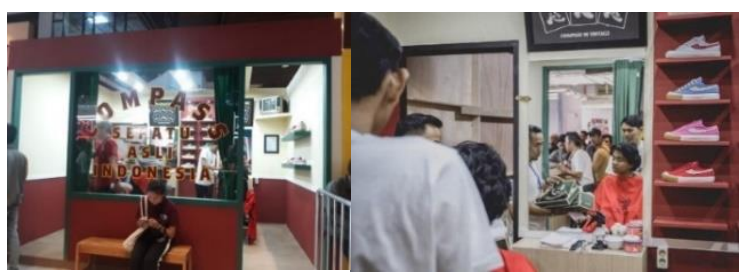

Figure 8. Exhibition Booth Compass in Urban Sneakers Society 2019

Source : www.urbanasia.com (2019)

The use of an exhibition booth or exhibition stand as the front line of the marketing process of a product, as well as being the branding image of the company. Designing an attractive exhibition booth or exhibition stand will bring in many consumers, so that it can increase the selling value of the products on display at the event. The local sneaker brand Compass 
presents a unique and communicative visual exhibition stand concept to attract many visitors at the 2019 Urban Sneakers Society. In this exhibition, Compass shoes carry an exhibition booth with the concept of a barber shop. Physically, the building is in the form of a square measuring approximately $4 \times 3$ meters with a characteristic on the front glass window of the exhibition stand emblazoned with the words Compass Sepatu Asli Indonesia. In the exhibition booth there is a large glass and two chairs as well as other vintage collectibles such as a tube television that is displayed in the corner of the room wall, while the front of the visitor is attached to the Compass shoe arrangement, which is offered in a variety of color choices. The local sneaker brand Compass applies applicable rules or regulations to limit the number of each buyer (consumer) entering the exhibition booth area, this is done to maintain the circulation of the room so that it is not too narrow and facilitate access in and out for visitors to the exhibition stand. In the transaction process of buying and selling Compass Gazelle sneaker shoes, each prospective buyer will be welcome by a salesman to sit on a chair using a cloth like the service in a barber shop. The salesman will be in charge of asking the buyer about the type and size of the sneaker they want before purchasing the product.

Compass local sneaker brand marketing strategy by using word of mouth communication (WOM) in addition to increasing sales of these shoe products, but also aims to build marketing communication by making product offerings based on consumer needs. The form of selling Compass sneakers uses direct (face-to-face) communication between the seller and prospective customers to introduce a product to potential customers and form a customer's understanding of the product. Personal Selling is the interaction between individuals, face to face with the aim of creating, repairing, controlling, or maintaining mutually beneficial exchange relationships with other parties (Swastha, 2002: 260). In the sneaker exhibition, a marketing strategy of exclusively distributing local sneaker products is implemented by producers (sellers) so that the goods can reach the buyers or consumers. Distribution is a very important activity in the marketing system because the distribution is effective and efficient, the goods will be quickly marketed and then purchased and consumed by consumers of these goods or products. Fandy Tjiptono, Gregorius Chandra and Dadi Adriana in Strategic Marketing (2008), explained that exclusive distribution is the marketing activity of a product carried out by a company using only a large trader or retailer in a certain market area. The involvement of local sneaker brands in the exhibition has become product oriented campaigns to get attention from consumers to choose products made in the country (local). Product oriented campaigns are activities in product-oriented campaigns and are usually carried out in commercial activities, marketing promotion campaigns, of new product launches (Ruslan, 2008: 25). This type of campaign is generally carried out within a commercial business environment that aims to build a positive image of the product introduced to the public.

The main key to the success of a business is the trust that arises from consumers in the products and services being sold. Therefore, a marketing strategy is needed by communicating effectively to customers that is transparent and more open. High brand awareness can result in brands having advantages in the minds of consumers over competing brands during the purchasing decision-making process for these products. Awareness describes the existence of a brand in the minds of consumers, so that it becomes a determinant in having a key role in brand equity (Durianto et al., 2004: 6). The NAH Project is a local Indonesian shoe brand manufacturer that pioneered the use of the transparency pricing method or price penetration in increasing the marketing (sales) of these products or goods which have an effect on consumer confidence (buyers). Cost transparency is an economic exchange communication that builds relationships between customers (consumers) and producers (sellers) to build trust. The cost transparency phenomenon is a hallmark of business in the digital era which is practiced virtually in order to be able to find out the cost (cost) of a company to create or produce a product or service (Ferguson, Jodie L. \& Ellen, Pam Scholder, 2013: 405). Transparency pricing or price penetration can be a method for consumers (buyers) to compare the price of a product or item from one distributor or producer (seller) to another to get the cheapest price.

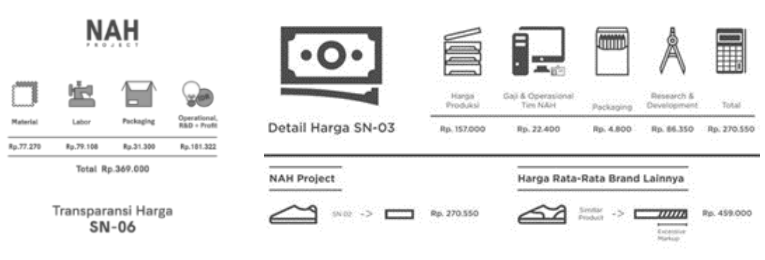

Figure 9. Transparency Pricing of Shoes Nah Project

Source : www.nahproject.com (2019)

When viewed from a prospective buyer (demand site), the cost transparency concept has two important aspects that can influence the 
formation of the final price in the process of creating or producing a product or item. Competitor factors in a business that will make potential customers (buyers) be given access to select these products or goods cheaper, higher quality, and faster. Cost transparency also affects the psychology of a prospective buyer (consumer), so that the person concerned can find out or construct from the production costs of these goods. Related to the decision to buy a product or goods in influencing the lifestyle of the Indonesian people. This consumer behavior can be differentiated based on the tendency to accept various domestically-made products by rejecting imported products which is known as consumer ethnocentrism. By definition, consumer ethnocentrism is a consumer preference for domestically-made products and rejects imported products (Sharma, et al., 1995: 11-19). A high level of consumer ethnocentrism in society will result in brand awareness by forming a positive attitude towards purchasing local products, in addition to consumer perceptions it is also influenced by government policies by limiting imported commodities on products or goods that can be made domestically. The influence of the country of origin a shift in the consumption pattern of the people by showing pride and support for local products. $\mathrm{COO}$ (Country of Origin) is a mental association and belief that is triggered by a country (Kotler \& Keller, 2009: 338).

\subsection{Brand Campaign Effectiveness with Local Pride Tagline}

With the growing influence of business in the digital era, more and more local sneaker brand manufacturers are relying on promotional media with social media platforms such as Instagram using the hashtag \#LocalPride and \#LocalPridelndonesia to increase sales of a product or item to potential consumers (buyers). Consumers can easily find various local sneaker brands made in Indonesia by using the scroll feed on Instagram, Twitter and other social media platforms. The tagline or slogan is part of a promotion of goods or services that aims to make it more attractive and easy to remember by consumers. Taglines have traditionally been interpreted as jingles or slogans. The tagline must be easy to remember, simple and short word choice (Soebroto 2013: 263). The tagline becomes an identity system, in the form of one or more words that describe the essence, personality and brand positioning. The tagline is a short sentence as the closing of the core text that briefly summarizes the communication objectives of an advertisement or promotion.
The tagline is a short expression containing a message that is solid and easy for consumers to remember (Nuradi et al., 1996: 56). The tagline is a marketing strategy used to dramatize the emotions and functionality of a brand of an item or product with an approach to potential potential customers. A tagline must be created by understanding product insight and consumer insight that give birth to product positioning, then a marketing strategy that is translated into consumer language and a tagline of the product or item is created (Yektiningsih, 2010: 44). The introduction of the tagline (slogan) was carried out through the above the line (ATL) program in the form of advertising in various print and electronic mass media. The tagline which serves to form a brand image of a product or item in the minds of consumers is not only a premise but will change by following a promotional language style tailored to market segmentation.

Instagram began to develop from what was originally just a social media platform to communicate, but in the digital marketing era, it has become one of the media that provides various information from clothing styles to news that is viral in the community. In recent years, business accounts on Instagram have started to appear using names that carry the concept of local pride, such as @localprideindonesian, @localprideindonesia, @localpridegarage and so on. The majority of these Instagram accounts raise the headline "Bangga Produk Buatan Indonesia " by providing information in the form of uploads that contain clothing styles that are able to attract the attention of their followers to trendy dress styles. The presence of Instagram also has an impact on social changes on fashion trends in society, especially the younger generation (millennial). The use of the hashtags or hashtags \#LocalPride and \#LocalPridelndonesia is able to carry out its function to build a local product brand and build consumer trust which can be measured through three indicators, namely familiarity that consumers can easily remember and recognize when posted as a link on Instagram social media. Besides being able to be used as branding to build a self-image (image branding) of a brand or company to consumers and the audience (society). Functionally, hashtags or hashtags can also make it easier for potential buyers (consumers) to find posts on local shoe products on social media, then it is useful in categorizing incoming messages via digital devices so that they can be easily searched for by internet users. 

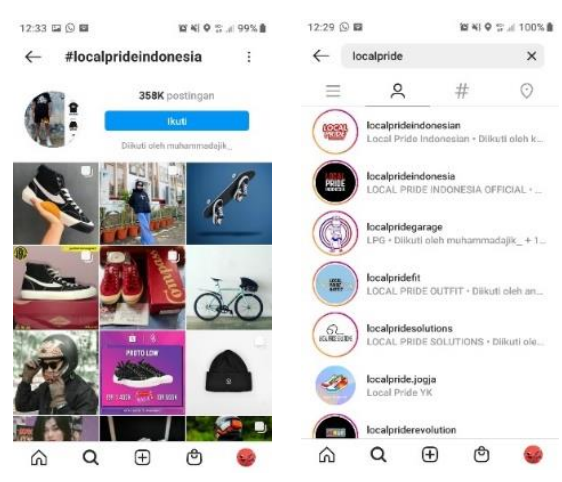

Figure 11. Local Pride Themed Instagram Business Account

Source : Instagram (2021)

Differentiation is a characteristic of a product compared to its competitors or competitors, so that it is able to highlight the superior Indonesian (local) products produced in order to compete with products made from abroad. The use of hashtags or hashtags into marketing content that aims to attract consumers is undeniably starting to develop in the digital business era. In hindsight, international label shoe brands with iconic slogans such as Vans "Off the Wall", Nike "Just Do It", Adidas "Impossible is Nothing", Converse "Shoes are boring. Wear sneakers", ASICS "Anima Sana In Corpore Sano" and so on. In recent years, the tagline or slogan carrying the theme of local brand support has become a popular and familiar phrase in the ears of the Indonesian public, such as Compass shoes with the jargon "Sepatu Untuk Rakyat", Blaxfootwear "Sepatunya Rakyat", and Ventela "Brand Lokal Desain Internasional". However, there are also local shoe brands that argue that they don't use slogans or taglines with locality-inspired movements to attract consumers attention and generate a sense of love and pride for local products, such as Piero "Make Your Move", Pijak Bumi "Eco-Friendly and Sustainable Footwear for Better Earth", Geoff Max "Ready To Kick", Brodo "We Have a Bright Future", Saint Barkley "Your Choes Your Shoes", Seba Shoes "A Pair Of Shoes Can Change Your Life", Sage Footwear "Good Steps in All Directions", Homyped "Nyaman Di Kaki Pas Di Hati", and Ricosta "Limitlesss Identities". The hashtags in addition to being a brand campaign to describe the vision and mission of a company to consumers, but also aim to attract the attention of the public. then it gives a curious effect of potential buyers (consumers) which converts into purchasing power of the advertised product. A good (effective) tagline has certain qualities that make it available. can work and benefit a product brand by meeting the criteria, namely it conveys a brand's point of difference, it Faculty of Economics and Business, Brawijaya University differentiates a business from all others and it reflects the brand's identity, character, promise, and personality (Chiaravalle \& Schenck, 2015).

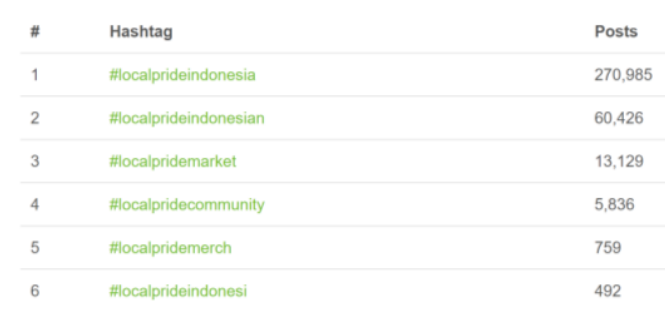

Figure 12. Number of Posts with Hashtag \#LocalPride on Instagram

Source : www.best-hashtags.com (2020)

In social media, a hashtag is a word or phrase that begins with a hashtag using (symbol $\#$ ) which is often used by social media users to create posts showing love and pride for local shoe products, especially those made by micro, small and medium enterprises. The hashtags \#LocalPride and \#LocalPridelndonesia in increasing engagement on Instagram social media also have an impact on the brand image of local shoe products, so that consumers have loyalty to the products produced by the company. Lianxi Zhou and Michael K. Hui in the journal Symbolic Value of Foreign Products in the People's Republic of China (2003) concluded that local brands are preferred over foreign brands. In digital content marketing, the use of hashtags are labeled proudly using Indonesianmade products is able to increase sales of local shoe products through e-commerce, as well as being a promotional tool that has proven to be very effective in increasing the number of followers of social media accounts. The intensity of using the hashtags \#LocalPride and \#LocalPridelndonesia has increased every year since they are used on Instagram social media. The function of the tagline as a message of value that measures the level of effectiveness of the delivered promotion can attract attention, be understood, understood, arouse emotions and move the target to provide the desired response, so that it affects purchasing decisions. done by consumers. The Compass shoe is a local sneaker brand that has canceled the launch of two collaboration series Compass Darahku Biru and Vintage 98, as published on the Instagram social media Compass shoes on December 14, 2019. The Compass shoes with the Darahku Biru series were canceled to be launched at the Wall of Fades event. which was due to the booming queue of visitors and the unfavorable atmosphere of the sneaker enthusiasts at the Grand Indonesia Mall, Jakarta. However, the Compass Darahku Biru sneaker was finally sold with a flash sale through the Tokopedia online 
store on January 27 and 28,2020 . Flash sale is an offering of products or goods with limited discounts and quantities in a short time. Flash sales or what is also called a daily deal are part of a sales promotion that gives customers special offers or discounts for certain products or items for a limited time (Zakiyyah, 2018: 64). The release of the Compass shoe sold out in a matter of hours, earning it the nickname the "Sepatu Gaib" for being a rare item in physical stores and online sales forums.

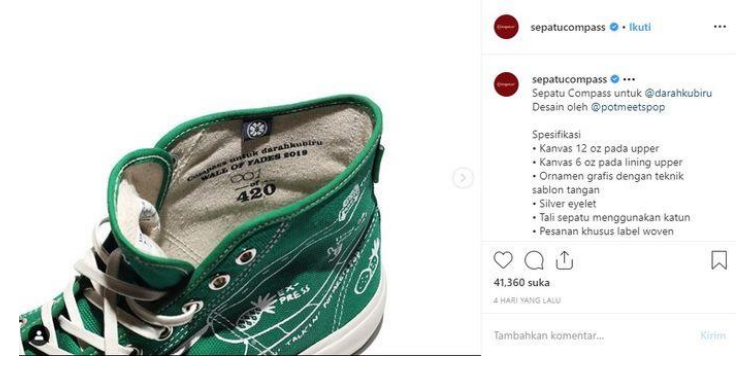

Figure 13. Promotion Compass $X$ Darahku Biru on Instagram

Source : @sepatucompass (2019)

Actions by entrepreneurs to develop local wisdom-based products by intensifying love campaigns for local products in the last few years have actually started to be made effective by the government as a stakeholder. In 2009, a national campaign aimed at promoting Indonesian brands, brands and products had actually been initiated by the Ministry of Trade of the Republic of Indonesia and the Ministry of Communication and Information of the Republic of Indonesia, namely $100 \%$ Cinta Indonesia. On May 14, 2020, President Joko Widodo also launched Gerakan Nasional Bangga Buatan Indonesia (BBI) amidst the struggles of the Indonesian people in facing the Indonesian and global economic crisis and recession caused by the COVID-19 pandemic. The \#BanggaBuatanIndonesia tagline was born. mengiatkan campaign so that the Indonesian people buy products made in the country, either large businesses or micro, small and medium enterprises. In addition to buying products made in Indonesia, \#BanggaBuatanIndonesia movement also encourages multinational companies in Indonesia to increase domestic component level in producing products or goods that have quality and a global competitiveness index (GCl). If you look at the income statistics of the clothing and footwear industry in Indonesia, it also shows an increase every year. According to data on sales of clothing and shoes through e-commerce in Indonesia in Statista.com, it notes that clothing and shoe revenues jumped from USD 365 million in 2017 to USD 735 million in 2019. In 2014 statistics for footwear data in Indonesia - In 2019, the footwear industry's revenue reached 387 million US dollars at the end of 2018 and a CAGR (Compound Annual Growth Rate) of $16.7 \%$ per year until 2022.

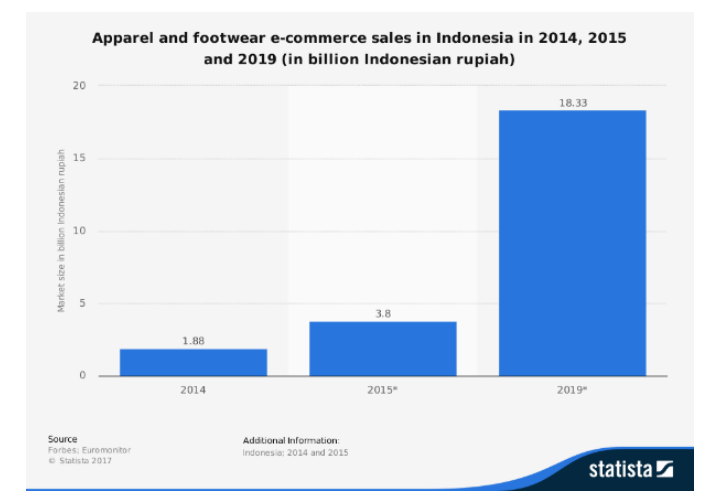

Figure 14. E-Commerce Sales of Clothing and Shoes in Indonesia 2014 - 2019

Source : www.statista.com (2021)

\section{Conclusions}

The emergence of the local pride movement or pride in using Indonesian products is a collective work of producers (sellers), consumers, communities, collectors and government (stakeholders). Collaboration across local sneaker brands with influencers to create special edition sneakers (design, material or material, and color choices) that are made in limited edition. Collaborative practice is an activity that aims to promote a new product or revive an old brand. This production limitation strategy is the exclusivity (prestige) of local sneaker brands, in addition to having an economic uplift impact but also aims to build brand personality for potential consumers (buyers). In recent years, the revival of the local sneaker market share in Indonesia has been on the rise, influenced by public confidence in domestic footwear exhibition activities. The level of consumer ethnocentrism towards local products in society has resulted in brand awareness by giving birth to a sense of nationalism and pride, such as the relatively more affordable prices of local sneakers and the quality of local products that are able to compete with global brand shoes. In the midst of the growth of social media users in Indonesia, digital marketing strategies are becoming a competitive brand by carrying a slogan or tagline with the proud theme of using local products through the hashtags or hashtags \#LocalPride and

Faculty of Economics and Business, 
\#LocalPridelndonesia. Local pride slogans or taglines that are deliberately designed to be a marketing gimmick by highlighting differentiation (factors that differentiate a product from another), brand positioning and using creativity (unusual marketing strategies to attract public attention (potential customers).

\section{References}

Aamidor, Aamidor. (2006). In Chuck Taylor, All Star: The True Story of the Man behind the Most Famous Athletic Shoe in History. USA: Indiana University Press

Adriansyah, Rizky. (2019). Perancangan Aktivitas Branding Sneakers Lokal dengan Studi Kasus Merek Sneakers Lokal Compass. Thesis, Universitas Pasundan.

Blake, J., \& Ernst, D. (1993). Collaborate to Compete in The Global Market. New Jersey: John Wiley and Sons.

Cherri, Cherri. (2020). Strategi Promosi Urban Sneaker Society melalui Akun Instagram dengan Memanfaatkan Tren Hypebeast pada Generasi Milenial. Thesis: Universitas Pelita Harapan.

Dharmawan, Osha Putra \& Handoyo, Pambudi. (2017). Fenomena Sneakers Impor (Studi Konstruksi Sosial Pemakaian Sneakers Impor). Journal Paradigma, 5(1), 1-8

Ferguson, Jodie L \& Ellen, Pam Scholder (2013). Transparency in Pricing and Its Effect on Perceived Price Fairness. Journal of Product and Brand Management, 22(5), 404-412.

https://doi.org/10.1108/JPBM-06-20130323

Freeman, R.E. (1984). Strategic Management: $A$ Stakeholder. Boston: Pitman

Kawamura, Yuniya. (2016). Sneakers : Fashion, Gender, and Subculture. United Kingdom: Bloomsbury Publishing.

Keyser, Amber. (2015). Sneaker Century : A History of Athletic Shoes. USA: Lerner Publishing Group, Inc

Lassar, W., Mittal, B., \& Sharma, A. (1995). Measuring customer-based brand equity. Journal of Consumer Marketing, 12(4), 1119.

https://doi.org/10.1108/073637695100952 70

Nastain, Muhamad. (2017). Branding dan Eksistensi Produk (Kajian Teoritik Konsep Branding dan Tantangan Eksistensi
Produk. Channel, 5(1), 14-26.

Permana, Sony Hendra. (2017). Meningkatkan Industri Sepatu atau Alas Kaki Nasional. Buletin APBN Pusat Kajian Anggaran Badan Keahlian DPR RI, 3-6.

Royan, F. M. (2005). Marketing Celebrities. PT. Elex Media Komputindo.

Susanto \& Hilmawan, W. (2004). Power Branding : Membangun Merek. Unggul dan Organisasi Pendukungnya. Jakarta: PT Mizan Publika.

Werry, Fredyan Ary. (2019). Pengaruh Pemasaran Digital dan Kualitas Produk Terhadap Keputusan Pembelian. Thesis. Universitas Sanata Darma Yogyakarta.

Van Gelder, Sicco. (2003). Global Brand Strategy. London: Kogan Page

Zakiyyah, A. M. (2018). Pengaruh Flash Sale Terhadap Pembelian Impulsif Online Pada Toko Online "Pulchragallery." Jurnal Manajemen dan Bisnis Indonesia, 4(1), 6370. https://doi.org/10.32528/jmbi.v4i1.1716

Zhou, Lianxi \& Michael K. Hui. (2003). Symbolic Value of Foreign Products in the People's Republic of China. Journal of International Marketing, 11(2), 36-58.

https://doi.org/10.1509/jimk.11.2.36.20163

\section{Internet}

https://www.statista.com/outlook/dmo/ecommer ce/fashion/footwear/indonesia

https://katadata.co.id/arsip/analisisdata/5f9a993 1ef083/mengandalkan-konsumsi-produk-lokaluntuk-memulihkan-ekonomi

http://sneakerdad.id/2018/03/13/senikolaborasi-sneakers

https://setkab.go.id/peresmian-gerakannasional-banggabuatanindonesiamelalui-telekonferensi-14-mei-2020-diistana-merdeka-provinsi-dki-jakarta 